\title{
Bridging the Digital Divide: Everyday Use of Mobile Phones Among Market Sellers in Papua New Guinea
}

\author{
George N. Curry, Elizabeth Dumu and Gina Koczberski
}

\begin{abstract}
Access to mobile technologies is transforming the daily lives of poor subsistence farmers in Papua New Guinea. However, the success of this access depends on infrastructure and where connectivity is poor there is evidence of a digital divide. Nevertheless, increasing affordability of internet access is helping to bridge the development gap.
\end{abstract}

Keywords ICT revolution • Developing world - Gender divide • Transformation

\section{Introduction}

Papua New Guinea, like many Pacific Island nations and most of the developing world, is experiencing an ICT revolution as access to information and communication technology (ICT) infrastructure expands rapidly (Cave 2012). This ICT revolution has the potential to revolutionise areas like agricultural extension (E-Agriculture), Health (E-Health), Banking (E-Finance) and Education (E-Education) (Cave 2012; Maumbe 2013; PRIF 2015). Ownership of mobile phones is expanding rapidly and smart phones are putting internet technology into the hands of poor subsistence farmers following a way of life largely outside the market economy (Curry and Koczberski 2013). The rapid uptake of ICTs by the poor can be attributed to greater affordability, accessibility, and adaptability of ICTs (McNamara et al. 2011; GSMA 2015).

The recent wave and adoption of new technologies and digital applications across the globe has been likened to a "Great Transformation" (Fuchs 2013, p. 16) that is fostering rapid growth in accessing information and new ways of producing,

G.N. Curry $(\bowtie) \cdot$ E. Dumu · G. Koczberski

Curtin University, Bentley, Australia

e-mail: G.Curry@exchange.curtin.edu.au

(C) The Author(s) 2016

M.E. Robertson (ed.), Communicating, Networking: Interacting,

SpringerBriefs in Global Understanding, DOI 10.1007/978-3-319-45471-9_5 
creating, sharing and communicating knowledge. It is suggested this revolution is at least as transformative as the Green Revolution technologies once heralded as the panacea for world hunger as they were rolled out across the developing world in the 1960 and 1970s (Fuchs 2013). This remarkable transformation is at once liberating and socially and economically empowering, with the potential to transform gender relations and bridge the economic and social divides within and between countries.

However, whilst there has been an enormous increase in ownership of, and access to, ICTs worldwide, the growth across the globe has been uneven. The developing and least developed countries lag well behind developed industrial countries in engaging in the digital age. Although the majority of people accessing the internet live in poor countries, per capita use is much lower than in developed nations. About 21 percent of the population of the developing world have internet access compared with around 84 percent of the developed world's population (ITU 2014). For example, while access to the internet has increased in PNG since the introduction in 2011 of a mobile broadband service and the expansion of high-speed 'third generation' (3G) and 4G mobile broadband networks, only 9 percent of the population have access to the internet (ITU 2014; see also Cave 2012; Logan 2012).

The digital divide is not only between countries, but within countries. Despite more rural people gaining access to ICTs in poorer countries, there remain large differences in the extent of network coverage between rural and urban areas. In a study of 17 Sub-Saharan countries in 2010, 69 percent of urban respondents owned a mobile phone compared with only 53 percent of rural respondents (Totora and Rhealt 2011). Similarly, a 'gender digital divide' is typical of many developing countries where women and girls have less access to ICT than men and boys (GSMA 2015). These divisions in the ownership of and access to ICTs further marginalise the rural poor and women from the benefits of social and economic change resulting from the expansion of ICT availability.

This chapter examines the extent to which a digital divide exists in PNG. The chapter reports on preliminary research on the recent uptake of mobile phones to investigate whether service and economic divides between urban and rural PNG and an entrenched gender bias in PNG are also reflected in new digital divides. The question this chapter addresses is whether mobile phone technology is bridging existing gender and spatial inequalities or simply reinforcing them. The chapter begins with a brief overview of spatial and gender inequalities in PNG and then considers how mobile phone technologies are being taken up and used by men and women in both urban and rural/remote locations. The data for the chapter are drawn from several research projects in which the authors are engaged: (1) fruit and vegetable sellers at informal markets in Mt Hagan, the capital of Western Highlands Province (WHP) and Kokopo, the capital of the island province of East New Britain (ENBP); (2) cocoa growing households in ENBP, Milne Bay (MBP) and the Autonomous Region Bougainville (ARB); and (3) oil palm smallholders in West New Britain (WNBP) and Oro provinces (OP) (Fig. 1). 


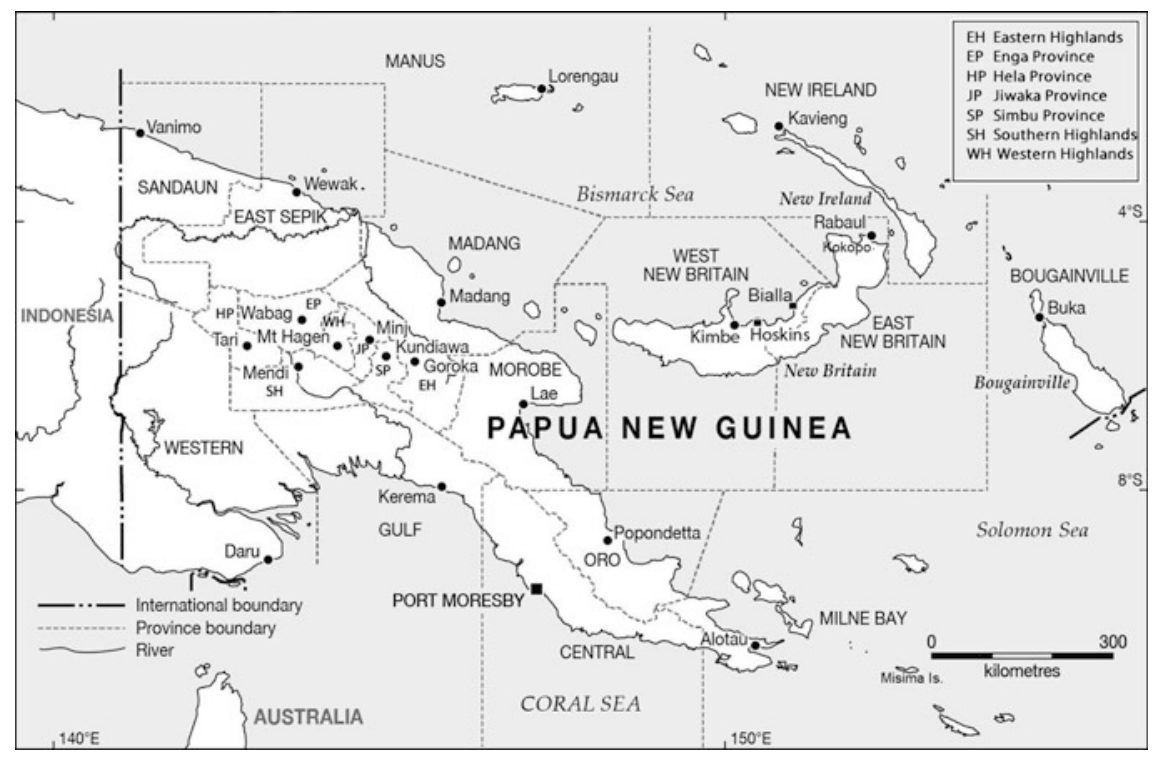

Fig. 1 Papua New Guinea

\section{Papua New Guinea}

PNG has experienced a mining and mineral boom over the past few decades (UNDP 2014), with GDP growth rates averaging above 6 percent for over ten years (ADB 2014). Despite this mineral-driven growth, poverty remains widespread with the majority of the population, especially the rural population, benefiting little from this growth. Approximately 87 percent of the national population of over 7 million live in rural villages and are highly dependent on agricultural-based activities to meet their everyday social and economic needs. Most people rely on their own food gardens for everyday consumption and for income, and there are very few cash-earning opportunities outside of agriculture. Nearly 90 percent of cash income in rural areas is from export cash crops such as cocoa and coffee and the local marketing of food crops and betel nut (Allen et al. 2001; Sharp 2012), with over two-thirds of this income from export cash crops.

\section{The Rural-Urban Divide}

The physical geography of PNG presents major challenges to the provision of basic infrastructure and services. Approximately 52 percent of the total land mass in PNG is classified as mountains and hills (Allen et al. 2005). Access to roads, health, education, telecommunication networks, and markets by rural villagers, especially 


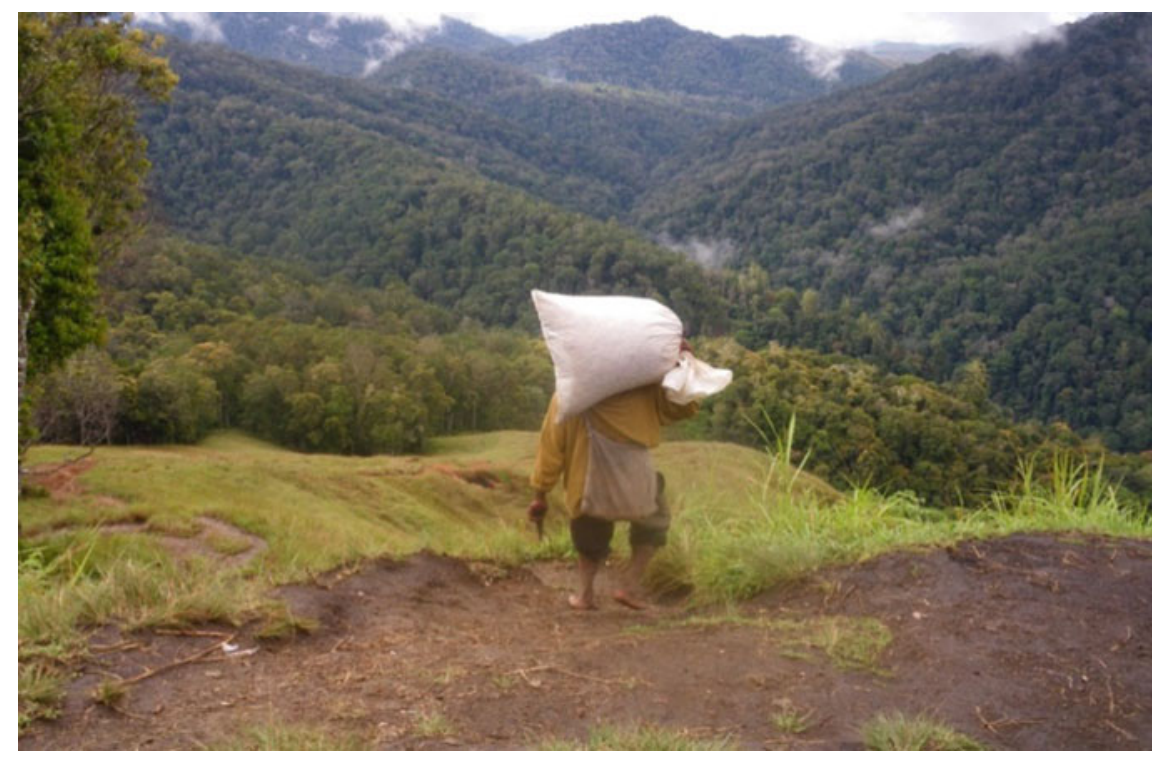

Plate 1 Coffee often has to be carried long distances to market in the PNG highlands

those isolated by rugged terrain (Plate 1) is very difficult and costly to the point that livelihood options are severely curtailed. Often migration to urban and rural resource development sites is the only viable option for people from these communities. Indeed, migrants from remote, poorly serviced and disadvantaged rural areas and small islands constitute a high proportion of the growing urban population (Koczberski et al. 2001; Storey 2010; Curry et al. 2012; Numbasa and Koczberski 2012).

The rural-urban divide is very marked in PNG and is apparent across a wide range of variables including cash income levels, food security, education and literacy and a whole suite of health indicators. The UNDP (2014) point out that while an urban/rural divide in human development is common in many parts of the world, it is particularly stark in PNG. For example, despite fairly good access to customary land for most of the rural population, food poverty at 28.5 percent of the rural population has been estimated to be double the urban rate (NSO 2011). The poorer quality diets in rural areas are also reflected in adverse nutritional outcomes. Nationwide household surveys in 1996 found almost half of rural children were stunted compared with one-fifth of urban children (Gibson 2000). Rural people also have less access to primary health care compared with the urban population, and rural children are more likely to carry a greater burden of infection because of their poor access to good health care (Gibson 2000; Howes et al. 2014). Similarly, illiteracy is more prevalent in rural areas. At 40 percent, the rural illiteracy rate is three times the urban rate (13 percent) (NSO 2011; Kare and Sermel 2013). The considerable gap in literacy rates between urban and rural PNG reflects not only the poorer access to 
schools in rural and remote areas, but also the difficulty for schools in maintaining staffing levels to teach literacy and numeracy skills (Waffi et al. 2015). Such low rural literacy rates and the very different education levels between rural and urban PNG also help explain the lower nutritional status of rural children (Gibson 2000).

These service and income inequalities also apply to material conditions of living. In housing, for example, 72 percent of rural houses have walls constructed from bush materials compared with 7 percent of urban houses (NSO 2011). Roofing iron is highly prized in PNG and is considered to be an indicator of wealth and status. In rural PNG, 29 percent of houses are roofed with corrugated iron compared with 89 percent of urban homes (NSO 2011). In terms of durable household goods, the same pattern is repeated with urban households having much higher ownership rates of consumer goods. For example, almost half of urban households have a stove compared with just 4 percent of rural households; 46 percent have a refrigerator while less than 3 percent of rural households do so (NSO 2011).

\section{The Gender Divide}

PNG's constitution, written in 1973, has a provision for equal opportunities for all citizens. Despite its noble intentions, and PNG being signatory to several international conventions on gender equality (e.g., Convention on the Elimination of all Forms of Discrimination against Women - CEDAW), discrimination against women and girls is pervasive. The Gender Inequality Index (GII) ranks PNG 134 out of 148 countries (GoPNG 2013), and gender inequalities in PNG have proven extremely hard to address. On virtually every socio-economic and health indicator, women fare worse than men (GoPNG 2013), and the country is one of the few nations in the Asia-Pacific region yet to achieve gender equality at primary school level. Rates of gender-based violence are amongst the highest in the world (World Bank 2012a; GoPNG 2013; UNDP 2014): two-thirds of women are estimated to have experienced gender-based violence (GoPNG 2013). Women in PNG not only risk high rates of violence, but also have fewer economic opportunities than men, have high maternal mortality rates (over 100 times higher than the rate for Australia-UNICEF 2013) and shorter life expectancy than men. They also experience inequalities within the home which limits their access to household income and participation in decision-making (Overfield 1998; Wardlow 2006; Koczberksi 2007; Macintryre 2008; World Bank 2012b; UNDP 2014).

Education statistics also show a strong gender disparity, despite recent improvements (NSO 2011; UNDP 2014). PNG women are more likely to be illiterate, have lower levels of primary and secondary school attainment, and to be less represented (38 percent) at university level than men (e.g. Gannicott and Avalos 1994; Gibson and Rozelle 2004; ADB 2012; DFAT 2012; Kare and Sermel 2013; UNDP 2013). A higher proportion of males than females can read and write ( 69 percent compared to 57.3 percent) and just 6.8 percent of adult women have secondary or tertiary level education compared with 14.1 percent of men (UNDP 2013). 


\section{The Introduction of Mobile Phones to PNG}

The mobile phone was introduced in 2003 into a country where telecommunication networks are relatively recent. The first radio and telephone technologies were installed in Rabaul, ENBP in 1907 (Fig. 1) and over the following two decades they were extended to other major centres of the country (Sinclair 1984; Suwamaru 2013). In 1933, PNG established its first government information radio station and by 1975 , when PNG gained political independence, the telephone network was accessible only to a small group of the urban elite (Ogden 2013). Fixed line telephones remained out of reach of most of the population and in 2007 PNG had one telephone per 100 inhabitants; the lowest penetration rate among the Pacific Island nations (Ogden 2013; Crocombe 2001).

With limited telecommunication networks up until the introduction of mobile telephony, most information was relayed locally using traditional communication devices such as conch shells, drums, yodelling and slit-gongs (garamut). Radio and postal services were commonly used for communications over longer distances (Suwamaru 2013). As Telban and Vavrova (2014, p. 3) point out, prior to mobile telecommunications in PNG, "[r]emote villages were relying mainly on letters and tok save 'announcement, notification' over the radio or on traditional means of carrying the messages by either word-of-mouth or a drum signal". ${ }^{1}$

When mobile phone services were introduced, coverage was provided by the state-owned Telikom PNG monopoly and limited to major urban centres like Port Moresby, Lae, Madang, Goroka and Mt Hagen (DFAT 2004). In 2006 there was one mobile phone subscription per 100 people (World Bank 2012c). In 2007 mobile phone access improved considerably when the government removed the Telikom PNG monopoly on fixed line and mobile phone services, allowing new providers to enter the market. There are now three mobile phone providers in PNG. One of the first new players, Digicel, entered the market in July 2007. Within eight months of Digicel's arrival, coverage had expanded from two to ten per cent of the population (Watson 2011), and by 2010 it had reached 28 percent of the population (World Bank 2012c). This initial rapid uptake of mobile phones is reflected in the data collected for WHP and ENBP, with most of the uptake occurring within two years of the arrival of Digicel services (Fig. 2). Over time, mobile phones have penetrated remote rural villages and outer islands that hitherto had been extremely poorly serviced, and often without electricity, health services, reticulated water or road access. By 2014, 41 percent of the population had mobile phone access (Suwamaru 2015).

\footnotetext{
${ }^{1}$ Radio 'tok save' is an announcement or message relayed over the radio waves via radio stations. People deliver hand-written messages to the radio station to be read on air to relatives and friends living elsewhere.
} 


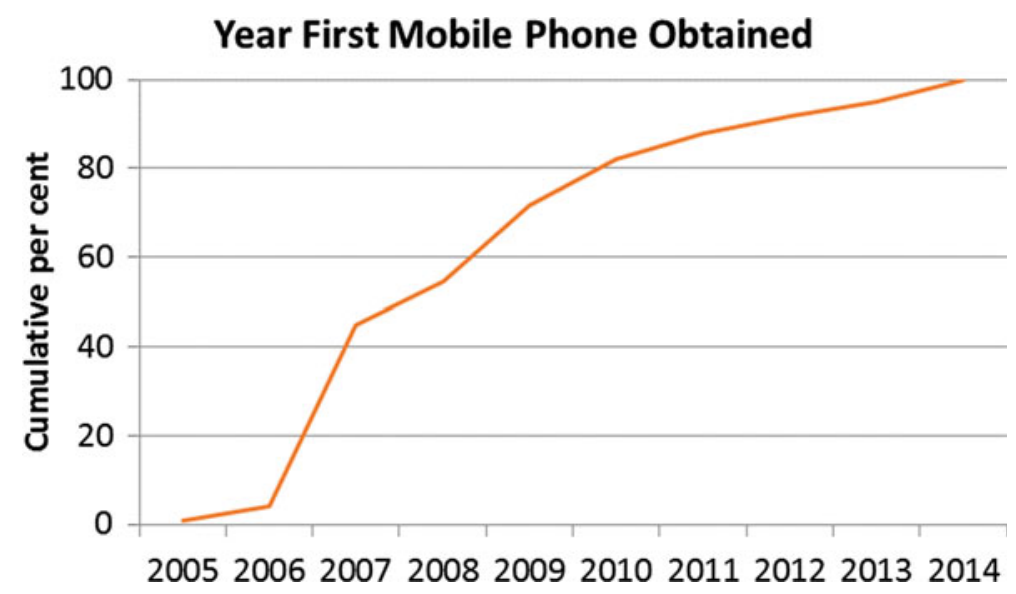

Fig. 2 The uptake of mobile phones in WHP $(n=51)$ and $\operatorname{ENBP}(n=24)$

More recently there has been significant growth in the use of mobile broadband to access the internet. This is driving the massive rise in the use of social media in PNG. By November 2015, there were 625,874 internet users (Internet World Stats 2015). Facebook is the most common use of the internet and it is the largest online network in the Pacific with around 700,000 Facebook users in Pacific Island Countries (PRIF 2015). In November 2015 there were over 350,000 registered users of Facebook in PNG, many of whom were aged 18-24 years (Internet World Stats 2015; see also Logan 2012).

\section{The Rural-Urban Digital Divide}

Although the uptake of ICT continues to rise in PNG and network coverage continues to improve, preliminary evidence indicates that the so-called 'digital age' remains an elusive dream for many Papua New Guineans, especially those living in remote areas (Cave 2012). In 2010, 39 percent of households in four field sites in EHP owned a mobile phone. Although the data are not directly comparable, more recent data collected from urban markets in WHP and ENBP (sellers from relatively accessible locations), show that almost 100 percent of sellers or someone in their household owned a mobile phone. The same data set revealed that 75 percent of individuals over 18 years of age owned a mobile phone. Mobile phone uptake appears to be reaching saturation point, at least for some urban locations and rural villages with relatively good access to town.

There is, however, a clear spatial divide. Mobile phone ownership rates are considerably lower in remote rural locations than in urban areas or rural villages near town (Table 1). Initially, this urban-rural divide would have reflected mobile phone access and connectivity prior to 2007 when mobile telephony was limited to 
Table 1 Mobile phone ownership among export cash cropping households in PNG by remote and accessible locations* (percent of households)

\begin{tabular}{l|l|l|l}
\hline Location & Year** & $\begin{array}{l}\text { Accessible locations (percent of } \\
\text { households) }\end{array}$ & $\begin{array}{l}\text { Remote locations (percent of } \\
\text { households) }\end{array}$ \\
\hline EHP & 2010 & $66.5(\mathrm{n}=195)$ & $12.5(\mathrm{n}=137)$ \\
\hline WNBP & 2012 & $87(\mathrm{n}=206)$ & \\
\hline ENBP & 2014 & $99(\mathrm{n}=59)$ & \\
\hline WHP & 2014 & $99(\mathrm{n}=63)$ & \\
\hline ARB & 2015 & $84(\mathrm{n}=98)$ & \\
\hline ENBP & 2015 & $89(\mathrm{n}=88)$ & $40(\mathrm{n}=63)$ \\
\hline MBP & 2014 & & \\
\hline
\end{tabular}

*Accessible means within a half day's travel by road of a major urban centre

**Denotes year of data collection

major urban centres and areas close to town. Data collected in 2010 in the EHP (following the expansion of mobile coverage to rural areas), found that the rate of ownership of mobile phones in villages close to town was five times higher than in remote locations in the province. ${ }^{2}$ It is likely that this divide has become less marked through time as mobile phone coverage has expanded to include many remote areas. However, in 2014, on Misima Island, MBP the rate of phone ownership was about half that of the accessible sites (Table 1).

This rural-urban digital divide is more than simply a reflection of the spatial distribution of mobile phone services. As noted above, rural and remote PNG is disadvantaged on many indicators, including health, education and income. In Table 1 mobile phone ownership was high among rural households in WNBP, ENBP and ARB who resided not far from town and had access to a regular income from export cash crops and the sale of fresh food produce at town markets. People living in remote rural areas, such as in parts of EHP and MBP have fewer opportunities to earn an income, and incomes tend to be much lower than in areas accessible to town. For example, in the relatively accessible sites in the EHP study, the average number of income sources per household (excluding coffee) was higher than in the remote sites and the potential to earn high incomes through the commercial production of vegetables was also significantly greater. Thus, acquiring and maintaining a mobile phone (e.g. charging batteries and phone charges) is a much greater financial challenge in remote locations.

Table 1 indicates that PNG, like other poor countries where there has been a large increase in the ownership of mobile phones, is showing signs of an entrenched digital spatial divide. It is possible that mobile phones will exacerbate the already stark rural-urban divide. Undoubtedly, people in rural and remote areas will benefit from new services that mobile phone telephony enables such as banking and possibly an extension of agricultural services. But the potential benefits of the

\footnotetext{
${ }^{2}$ The EHP fieldwork was in four sites: Bena and Asaro were accessible sites not far from Goroka town, and Marawaka and Baira were in remote parts of the province without road access.
} 
technology will be much greater in urban PNG and in villages close to town where people have greater capacity to capitalise on the development opportunities of this new technology. They already earn higher incomes which gives them greater capacity to access information on the internet. Improved market information delivered through mobile phones will enable people living near town to capitalise on these new opportunities while such opportunities will be less likely to be taken up by people in rural and remote areas.

\section{The Gender Digital Divide}

A 'gender digital divide' where women have less access to mobile phones than their male counterparts is also found in PNG (GSMA 2015). Watson (2011) found that men in Megiar, north of Madang in PNG, were more likely than women to own a mobile phone. This gender difference in mobile phone ownership was not detected at Watson's second field site of Orora on Karkar Island. If a gendered digital divide were present in PNG, one would anticipate that men would adopt the new technology earlier than women, and they would make more use of the technology because they have more political and economic power (higher incomes) than women.

In terms of early adoption of the technology, the 2014 data collected among market sellers in ENBP and WHP were not clear cut. At both sites the average year of adoption was 2008 for both men and women. However, in ENBP, women tended to adopt mobile phones slightly earlier than men and in WHP the reverse was the case with men adopting mobile phones earlier than women (Table 2). This gendered difference in the uptake of mobile phones between the two provinces reflects, in part, the relative status of women in the two provinces: the Gazelle Peninsula of ENBP is matrilineal and women certainly have more status than women in the strongly patrilineal highland societies of WHP.

Further evidence of this gendered difference in mobile phone telephony between matrilineal ENBP and patrilineal WHP is reflected in rates of mobile phone ownership (Table 3). While men in both provinces have higher rates of phone

Table 2 The average year of when first mobile phone was acquired by gender for ENBP and WHP

\begin{tabular}{l|l|l|l}
\hline & Female & Male & Male and Female \\
\hline ENBP & 2008.40 & 2008.83 & 2008.72 \\
\hline WHP & 2008.72 & 2008.48 & 2008.64 \\
\hline
\end{tabular}

Table 3 Percentages of males and females over 18 years of age owning a mobile phone for ENBP and WHP

\begin{tabular}{l|l|l|l}
\hline & Female & Male & Male and Female \\
\hline ENBP & 70.59 & 81.39 & 76.21 \\
\hline WHP & 62.18 & 87.85 & 74.34 \\
\hline
\end{tabular}


Table 4 Average numbers of outgoing and incoming calls and SMS messages per day by gender for ENBP and WHP

\begin{tabular}{l|l|l|l|l|l}
\hline & $\begin{array}{l}\text { Mobile phone use (average } \\
\text { per day) }\end{array}$ & $\begin{array}{l}\text { Female } \\
\text { ENBP }\end{array}$ & $\begin{array}{l}\text { Male } \\
\text { ENBP }\end{array}$ & $\begin{array}{l}\text { Female } \\
\text { WHP }\end{array}$ & $\begin{array}{l}\text { Male } \\
\text { WHP }\end{array}$ \\
\hline \multirow{2}{*}{ Calls } & Outgoing & 1.41 & 0.79 & 1.39 & 2.02 \\
\cline { 2 - 6 } & Incoming & 1.03 & 0.78 & 1.68 & 2.27 \\
\hline \multirow{2}{*}{ SMS } & Outgoing & 0.43 & 0.1 & 0.21 & 0.86 \\
\cline { 2 - 6 } & Incoming & 0.4 & 0.5 & 0.8 & 1.17 \\
\hline
\end{tabular}

ownership than women, the gender disparity is more marked in WHP where a strong ideology of male dominance leaves women with less social, political and economic autonomy and power than men. There is a 25.7 percent point difference in phone ownership between men and women in WHP compared with a 10.8 percent point difference in ENBP. Clearly, the relative social and economic status of women in the two provinces is reflected in phone ownership rates.

These gender differences by provinces are also apparent in how the mobile phone is used and how frequently men and women make and receive calls and SMS messages. In matrilineal ENBP, women make and receive more calls than men, whereas in patrilineal WHP the reverse is the case and again the disparity between the genders is starker than in ENBP (Table 4). Similarly, in ENBP, women send more SMS messages than men and receive about the same number as men, while men from WHP send and receive more texts than women (Table 4).

In summary, it seems that mobile phone technology is not yet contributing to a significant erosion of the gender divide in WHP society. However, it is likely that mobile phone technology is empowering women by widening their social networks beyond their immediate communities by allowing them to maintain contact with relatives and friends living elsewhere. This is especially important for women in patrilineal societies when they move to the villages of their husbands and have limited contact with their natal relatives living elsewhere. It is also likely that the technology empowers women market sellers economically through, for example, enabling them to contact relatives in town to determine prices at local markets before committing to transporting garden produce to market. These benefits, of course, pertain more to women in accessible locations not far from urban markets who can respond quickly to such opportunities.

Overall, however, when ENBP and WHP are compared it appears that the uptake and use of mobile phone technology reflects existing patterns of gender inequality. Women in matrilineal ENBP have much higher status in their society and this is reflected in their higher rate of mobile phone adoption and use relative to men, whereas in patrilineal WHP with an entrenched high level of gender inequity, men are clearly benefiting far more from the new technology than women. 


\section{Conclusion}

While the adoption and spread of mobile phone technology in PNG has been nothing short of spectacular in a 'big bang' expansion and adoption of the technology, the jury remains out in the capacity of the technology to bridge the rural-urban and gender divides which are so pronounced in PNG. Clearly, there are major development benefits from adopting the technology. While men and women residing in remote locations and urban centres will benefit, it is debatable whether the technology will enable a 'catch-up' where women's social and economic status relative to men will increase and people living in remote areas will improve their economic situation relative to urban dwellers. As the data have revealed, the uptake and use of the technology has reflected the relative status of men and women with women in ENBP having greater gender equity in the adoption and use of the technology than their female counterparts in WHP where women's status is much lower than men. One potential consequence of the digital divide is a growing 'knowledge divide' along gender lines and between urban and accessible PNG on the one hand, and rural and remote PNG on the other hand.

Also, because the social and development benefits that mobile phone technology delivers will be greater in accessible locations than in remote locations, mobile phones may exacerbate existing spatial inequalities and further marginalise the rural poor. People in remote areas simply cannot act on the information that mobile phones deliver in the same way that people near town can do. High prices in town markets, for example, mean that a vegetable grower or a coffee producer living near town can act more quickly on that information than a producer in a less accessible location.

Finally, the rural-urban digital divide may also exacerbate the gender divide in mobile phone technology, such that the gender inequalities in ICT access in rural areas are more pronounced than in urban areas. This gender divide overlain and exacerbated by the rural-urban divide is not simply because of greater network coverage and incomes in urban areas, but is also likely to reflect the differential status of women in rural and urban PNG. Women's status in urban PNG has improved with modernisation and development, whereas in rural and remote PNG, traditional gender roles and the relative status of men and women have remained largely unchanged. One would anticipate that the capacity of mobile phones to erode gender divides and improve the status of women will be stronger in rapidly modernising urban centres and villages close to urban centres thereby adding a spatial dimension to the gender divide.

Acknowledgments Data collection on mobile phone ownership among oil palm smallholders in WNBP and cocoa smallholders in ENBP, ARB and Milne Bay was done in collaboration with researchers from the PNG Oil Palm Research Association and the Cocoa and Coconut Institute, PNG, respectively. Data collection in EHP in 2010 was in association with PNG Coffee Industry Corporation. We are grateful for the cooperation of villagers who gave their time to be interviewed. 
Open Access This chapter is distributed under the terms of the Creative Commons Attribution 4.0 International License (http://creativecommons.org/licenses/by/4.0/), which permits use, duplication, adaptation, distribution and reproduction in any medium or format, as long as you give appropriate credit to the original author(s) and the source, provide a link to the Creative Commons license and indicate if changes were made.

The images or other third party material in this chapter are included in the work's Creative Commons license, unless indicated otherwise in the credit line; if such material is not included in the work's Creative Commons license and the respective action is not permitted by statutory regulation, users will need to obtain permission from the license holder to duplicate, adapt or reproduce the material.

\section{References}

ADB (Asian Development Bank). 2012. Papua New Guinea: Critical development constraints. Mandaluyong City. http://www.nicta.gov.pg/publicinquirynew/\%20\%20RSD\%202nd\% 20Discussion\%20Paper/Digicel\%20Response\%20ADB\%20PNG\%20-\%20critical\% 20development\%20constraints.pdf. Accessed 15 May 2013.

ADB (Asian Development Bank). Asia Development Outlook 2014. Manila: ADB.

Allen, B., Bourke, R.M. and Hanson, L. 2001. Dimensions of PNG village agriculture. In Bourke, R.M., Allen, M. \& Salisbury J. (eds), Food Security for Papua New Guinea, pp. 529-553. Proceedings of the Papua New Guinea Food and Nutrition 2000 Conference, ACIAR Proceedings No. 9. Canberra: Australian Centre for International Agricultural Research.

Allen, B., Bourke, R. M. and Gibson, J. 2005. Poor rural places in Papua New Guinea. Asia Pacific Viewpoint, 46(2), 201-217.

Cave, D. 2012. Digital Islands: How the Pacific's ICT Revolution is transforming the Region. Sydney: Lowy Institute for International Policy, New South Wales.

Crocombe, R. 2001. The South Pacific. Suva, Fiji: University of the South Pacific.

Curry, G.N., Koczberski, G. and Connell, J. 2012. Introduction: enacting modernity in the Pacific? Australian Geographer 43(2), 115-125.

Curry, G.N. \& Koczberski, G. 2013. Development Implications of the Engagement with Capitalism: Improving the Social Returns of Development. In: McCormack, F. \& Barclay, K. (eds) Research in Economic Anthropology, Engaging with Capitalism: Cases from Oceania, pp 335-352. Bingley: Emerald Group Publishing Limited.

DFAT 2004. Annual Report 2004-2005. http://dfat.gov.au/about-us/publications/corporate/ annual-reports/annual-report-2004-2005/downloads/CompleteAnnualReport.pdf. Accessed 12 Jan 2016.

DFAT 2012. Annual Report 2012-2013. http://dfat.gov.au/about-us/publications/corporate/ annual-reports/annual-report-2012-2013/pdf/dfat_annual_report_1213.pdf. Accessed 12 Jan 2016.

Fuchs, R. 2013. Introduction Part I, From Heresy to Orthodoxy: ICT4D at IDRC. In: Elder, L., Emdon, H., Fuchs, R. \& Petrazzini, B. (eds) Connecting to ICTs to Development. The IDRC Experience, pp 1-16. London: Anthem Press.

Gannicott, K.G. and Avalos, B. 1994. Pacific 2010: Women's Education and Economic Development in Melanesia. Canberra: National Library of Australia.

Gibson, J. 2000. Who's Not in School? Economic barriers to universal primary education in Papua New Guinea. Pacific Economic Bulletin 15, 46-58.

Gibson, J. and Rozelle, S. 2004. Is it Better to be a Boy? A disaggregated outlay equivalent analysis of gender bias in Papua New Guinea. The Journal of Development Studies 40, 115-136. 
GoPNG 2013. The Future We Want. Voices from the people of PNG. Post-2015 Development Agenda Country Consultations. http://www.undp.org/content/dam/papua_new_guinea/docs/ MDG/UNDP_PG_The\%20future\%20We\%20Want\%202015.pdf. Accessed 15 January 2016.

GSMA. 2015. The Mobile Economy: Pacific Islands 2015. https://gsmaintelligence.com/research/? file $=23485245295 f 02524925 \mathrm{~b} 2 \mathrm{bd} 3 \mathrm{aeec} 6 \mathrm{de} \&$ download. Accessed 12 Jan 2016.

Howes, S., Mako, A.A., Swan, A., Walton, G., Webster, T. and Wiltshire, C. 2014. A lost decade? Service delivery and reforms in Papua New Guinea 2002 -2012. Canberra: The National Research Institute and the Development Policy Centre.

Internet World Stats 2015. Internet Usage and 2015 Population in Oceania: From wealth to wellbeing. http://www.internetworldstats.com/stats6.htm. Accessed 12 Jan 2016.

ITU. 2014. Measuring the Information Society Report 2014 Highlights. http://www.itu.int/en/ newsroom/Documents/MIS-2014-Highlights.pdf. Accessed 12 Jan 2016.

Kare, P. and Sermel, R. 2013. Providing Relevant and Quality Learning: An Aim of Universal Basic Education. In: Kukari, A. (ed). Universalizing Basic Education in Papua New Guinea: experiences, lessons learnt, and interventions for achieving the goal of universal basic education, pp 83-94. Port Moresby: The National Research Institute.

Koczberksi, G. 2007. Loose fruit mamas: Creating incentives for smallholder women in oil palm production in Papua New Guinea. World Development 35, 1172-1185.

Koczberski, G., Curry, G.N. and Gibson, K. 2001. Improving productivity of the smallholder oil palm sector in Papua New Guinea: a socio-economic study of the Hoskins and Popondetta schemes. Canberra: Department of Human Geography, Research School of Pacific and Asian Studies, Australian National University.

Logan, S. 2012. Rausim! Digital Politics in Papua New Guinea. SSGM Discussion Paper 2012/9. Canberra: Australian National University.

Macintryre, M. 2008. Police and thieves, gunmen and drunks: Problems with men and problems with society in Papua New Guinea. The Journal of Anthropology 19(2), 179-193.

Maumbe, B. 2013. Global e-Agriculture and Rural Development: E-Value Creation, Implementation Challenges, and Future Directions. In: Maumbe, B. and Patrikakis, C.Z. (eds), E-agriculture and Rural Development: Global Innovations and Future Prospects, pp 1-15. Hershey, Pennsylvania: IGI Global.

McNamara, K., Belden, C., Kelly, T. Pehu, E. and Donovan, K. 2011. Introduction: ICT in Agricultural Development (Module 1). In: World Bank (ed), ICT in Agriculture Connecting Smallholders to Knowledge, Networks, and Institutions, pp 3-14. E-sourcebook, The International Bank for Reconstruction and Development/World Bank, Washington. https:// www.ictinagriculture.org/content/ict-agriculture-sourcebook. Accessed 10 January 2016.

National Statistical Office (NSO) 2011. Household Income and Expenditure Survey 2009-2010. Summary Tables. Port Moresby: National Statistical Office.

Numbasa, G. and Koczberski, G. 2012. Migration, informal urban settlements and non-market land transactions: a case study of Wewak, East Sepik Province, Papua New Guinea. Australian Geographer 43(2), 143-161.

Ogden, M.R. 2013. Communications. In: Rappaport, M. (ed). The Pacific Islands. Environment and Society, pp 401-416. Honolulu: University of Hawaii Press

Overfield, D. 1998. An investigation of the household economy: coffee production and gender relations in Papua New Guinea. Journal of Development Studies 34(5), 52-72.

PRIF 2015. Economic and Social Impact of ICT in the Pacific 2015. Sydney: Pacific Region Infrastructure Facility.

Sharp, T.L.M. 2012. 'Following Buai: the highlands betel nut trade, Papua New Guinea'. Unpubl. $\mathrm{PhD}$ thesis, Canberra: Australian National University.

Sinclair, J. 1984. Uniting a Nation: the Postal and Telecommunication Services of Papua New Guinea. Melbourne: Oxford University Press.

Storey, D. 2010. Urban Poverty in Papua New Guinea, The National Research Institute, Discussion Paper No. 109, Port Moresby.

Suwamaru, J.K. 2013. ICT initiatives in Papua New Guinea: impact of mobile phones on socio-economic development. Unpubl. PhD thesis, Madang: Divine Word University. 
Suwamaru, J.K. 2015. Aspects of mobile phone usage in Papua New Guinea: a socio-economic perspective. Contemporary PNG Studies. DWU Research Journal 22.

Telban, B., and Vavrova, D. 2014. Ringing the living and the dead: mobile phones in a Sepik society. The Australian Journal of Anthropology 3(1), 1-15.

Totora, B. and Rhealt, M. 2011. Mobile Phone Access Varies Widely in Sub-Saharan Africa, Gallup New, September. Available at: http://www.gallup.com/poll/149519/Mobile-PhoneAccess-Varies-Widely-Sub-Saharan-Africa.aspx?g_source=position5\&g_medium=related\&g_ campaign=tiles. Accessed 15 January 2016.

UNDP 2013. Human Development Report 2013: The rise of the south. Human progress in a diverse world. http://hdr.undp.org/sites/default/files/Country-Profiles/PNG.pdf. Accessed 12 Jan 2016.

UNDP 2014. National Human Development Report. Papua New Guinea. From wealth to wellbeing: Translating resource revenue into sustainable human development. United Nations Development Programme, Port Moresby and Massey University, Auckland.

UNICEF 2013. Statistics at a glance: Papua New Guinea. http://www.unicef.org/infobycountry/ papuang_statistics.htm. Accessed 12 Jan 2016.

Waffi, J.M., Atigini, B., Sikas, H. and Hinamunimo, B. 2015. GoPNG - INGO Partnerships: A Case Study of CARE International in Papua New Guinea. http://devpolicy.org/Events/2015/2015PNG-Update/Presentations/Day-2/Public-private-partnerships_paper_Waffi.pdf. Accessed 15 January 2016.

Wardlow, H. 2006. Sexuality and Agency in a New Guinea Society: Wayward Women. University of California Press, Berkeley.

Watson, A.H. 2011. The mobile phone: The new communication drum of Papua New Guinea, West New Britain Province. Unpubl. PhD thesis, Brisbane: Queensland University of Technology.

World Bank 2012a. Papua New Guinea - Country gender assessment for the period 2011-2012. Washington: World Bank.

World Bank 2012b. World Development Report 2012: Gender Inequality and Development. Washington: World Bank.

World Bank 2012c. Information and Communications for Development. Maximising Mobile. Washington: World Bank. 